\title{
ANALISIS YURIDIS TENTANG RANCANGAN UNDANG-UNDANG HALUAN PANCASILA
}

Muhammad Rizqi Fadhlillah dan Yusmedi Yusuf

Fakultas Hukum, Universitas Islam Syekh-Yusuf

muhammad.rizqi@unis.ac.id

\section{Abstract}

Pancasila, which has become an ideology of the state, is currently facing a polemic with the Draft of the Pancasila Ideology (RUU HIP) proposed by members of the DPR. This polemic arose because the absence of TAP MPRS Number 25 MPRS/1966 of 1966 concerning the Disbanding of the Indonesian Communist Party, Statement as a Prohibited Organization in the Entire Territory of the Republic of Indonesia and the Prohibition of Every Activity to Spread Or Develop Communist/Marxist-Leninism and Pancasila Doctrine has been conceived to be squeezed into Trisila and Ekasila. The research method used in this study is normative research. The existence of the Draft Bill of Ideology is considered to change the basis of the state and change the state and national life order of the Indonesian people, therefore the Draft of the Pancasila Ideology Bow course must be rejected.

\section{Keywords: Draft Law; Pancasila; Ideology}

\section{Abstrak}

Pancasila yang telah menjadi ideologi negara saat ini sedang menghadapi polemik dengan adanya Rancangan Undang-Undang Haluan Ideologi Pancasila (RUU HIP) yang diusulkan oleh anggota DPR. Polemik ini timbul karena tidak dicantumkannya TAP MPRS Nomor 25/MPRS/1966 Tahun 1966 tentang Pembubaran Partai Komunis Indonesia, Pernyataan Sebagai Organisasi Terlarang Diseluruh Wilayah Negara Republik Indonesia Dan Larangan Setiap Kegiatan Untuk Menyebarkan Atau Mengembangkan Faham Atau Ajaran Komunis/Marxisme-Leninisme dan Pancasila yang sudah digagas akan diperas menjadi Trisila dan Ekasila. Metode penelitian yang digunakan di dalam penelitian ini adalah penelitian normatif. Adanya Rancangan Undang-Undamg Haluan Ideologi ini dianggap akan merubah dasar negara dan merubah tatanan kehidupan berbangsa dan bernegara pada masyarakat Indonesia, oleh karena itu Rancangan Undang-Undang Haluan Ideologi Pancasila harus ditolak.

\section{Kata kunci : Rancangan Undang-Undang; Pancasila; Ideologi}




\section{A. Pendahuluan}

Rechtstaat atau the rule of law dalam kepustakaan Indonesia sering diterjemahkan sebagai negara hukum, Notohamidjojo menggunakan rechtstaat dalam pengertian negara hukum, demikian pula halnya Muhammad Yamin yang menggunakan rechtstaat, government of law dalam pengertian negara hukum, disamping menggunakan istilah rechtstaat, ada juga yang menggunakan istilah the rule of law. ${ }^{1)}$ Indonesia merupakan negara hukum diuraikan dalam Pasal 1 ayat (3) yang menyatakan bahwa "negara Indonesia adalah negara hukum". Negara hukum yang ada di Indonesia memiliki ciri-ciri yang khas yang berasal dari Indonesia yaitu negara hukum yang berlandaskan Pancasila. ${ }^{2}$ Pancasila sebagai ideologi negara memiliki nilai-nilai kehidupan berbangsa dan bernegara dalam melaksanakan tujuan negara Indonesia sebagaimana tertuang dalam aline ke empat Pembukaan UUD 1945. Pancasila berisikan asas ketuhanan yaitu Ketuhanan Yang Maha Esa, asas kemanusiaan yaitu Kemanusiaan Yang Adil dan Beradab, asas persatuan yaitu asas Persatuan Indonesia, asas kerakyatan yaitu Kerakyatan Yang dipimpin oleh hikmat Permusyawaratan / Perwakilan, dan asas keadilan yaitu Keadilan sosial bagi seluruh rakyat Indonesia. Sehingga keberadaan Pancasila dapat digunakan sebagai penguji dari hukum positif yang ada di Indonesia, yang berarti segala pembentukan hukum dan penerapannya tidak lepas dari nilai-nilai Pancasila sebagai Staatsfundamental norm atau Norma dasar bernegara. ${ }^{3}$ Staasfundamentalnorm

1) Iriyanto A. Baso Ence, Negara Hukum dan Hak Uji Konstitusionalitas Mahkamah Konstitusi, (PT Alumni, Bandung: 2008), hal. 13.

${ }^{2}$ Sjahran Basah, Eksistensi dan tolak ukur badan peradilan administrasi negara di Indonesia, Cet ke 3 (Bandung : Alumni, 1985), hlm 11

3 Notonogoro, Pancasila dasar falsafah negara, kumpulan tiga uraian pokok -pokok persoalan tentang merupakan bagian dari teori jenjang hukum (Stufentheorie) yang dikembangkan oleh Hans Nawiasky murid dari Hans Kelsen. Staasfundamentalnorm adalah norma yang merupakan dasar bagi pembentukan konstitusi atau Undang-Undang Dasar dari suatu negara. Posisi hukum dari staatsfundamentalnorm adalah sebagai syarat bagi berlakunya konstitusi. A. Hamid S. Attamimi menerapkan teori yang dikemukakan oleh Hans Nawiasky pada struktur tata hukum Indonesia sebagai berikut : ${ }^{4}$

a. Staatsfundamentalnorm: Pancasila (Pembukaan UUD 1945)

b. Staatsgerundgesetz: Batang Tubuh UUD 1945, Tap MPR, dan Konvensi

c. Foemeel gesetz: Undang- Undang

d. Verodnung en autonome Satzung: Peraturan Pemerintah sampai Peraturan daerah.

Pancasila sebagai ideologi negara saat ini sedang menghadapi polemik yaitu adanya Rancangan Undang -Undang Haluan Ideologi Pancasila (RUU HIP) yang diusulkan oleh anggota DPR. Polemik ini timbul karena tidak dicantumkannya TAP MPRS Nomor 25/MPRS/1966 Tahun 1966 tentang Pembubaran Partai Komunis Indonesia, Pernyataan Sebagai Organisasi Terlarang Diseluruh Wilayah Negara Republik Indonesia Dan Larangan Setiap Kegiatan Untuk Menyebarkan Atau Mengembangkan Faham Atau Ajaran Komunis /Marxisme - Leninisme dan Pancasila yang sudah digagas akan diperas menjadi Trisila dan Ekasila. Penolakan adanya Rancangan Undang- Undang Haluan Ideologi Pancasila salah satunya digagas oleh Majelis Ulama Indonesia (MUI). MUI menyatakan

Pancasila, Cetakan kelima ,(Jakarta : Bina Aksara, 1983 ), hlm 53

${ }^{4}$ Jimly Asshiddiqie dan Ali Safa'at, Teori Hans Kelsen Tentang Hukum, (Jakarta: Konstitusi Press,2012), hlm. 154- 155 
bahwa tidak dicantumkannya TAP MPRS Nomor 25/MPRS /1966 Tahun 1966 tentang Pembubaran Partai Komunis Indonesia, Pernyataan Sebagai Organisasi Terlarang Diseluruh Wilayah Negara Republik Indonesia Dan Larangan Setiap Kegiatan Untuk Menyebarkan Atau Mengembangkan Faham Atau Ajaran Komunis /Marxisme - Leninisme dan Pancasila yang sudah digagas akan diperas menjadi Trisila dan Ekasila RUU HIP akan merubah berbagai aspek hukum dan norma yang sebelumnya sudah. Akan tetapi, dinamika publik soal urgensi dan substansi RUU dalam suatu negara hukum demokratis adalah hal yang wajar. Namun demikian, dinamika tersebut haruslah diletakkan dalam semangat berusaha mencari persetujuan bersama, oleh karena itu RUU HIP menarik untuk dikaji dari perspektif aspek yuridis.

\section{B. Metode Penelitian}

Jenis metode penelitian yang digunakan adalah metode penelitian hukum normatif, yaitu penelitian terhadap bahan pustaka yang merupakan data dasar yang dalam ilmu pengetahuan digolongkan sebagai data sekunder. ${ }^{5)}$ Penelitian hukum normatif berfungsi untuk memberi argumentasi yuridis ketika terjadi kekosongan, kekaburan, dan konflik norma. ${ }^{6}$ Metode penelitian merupakan persyaratan yang penting untuk menjawab permasalahan yang timbul dari latar belakang masalah yang berfungsi untuk mengarahkan penelitian. Sifat penelitian yang digunakan dalam penelitian ini adalah bersifat deskriptif, yaitu menggambarkan gejala- gejala di lingkungan masyarakat terhadap suatu kasus

5 ) Soerjono Soekanto dan Sri Mamudji, Penelitian Hukum Normatif, (Jakarta: PT. Raja Grafindo Persada, 2004), hlm. 24.

${ }^{6}$ I Made Pasek Diantha, Metodologi Penelitian Hukum Normatif,( Jakarta: PT Kharisma Putra Utama, 2016), hlm 12 yang diteliti. 7 ) Penulisan penelitian ini memerlukan serangkaian penelitian guna memperoleh jawaban atas pokok permasalahan yang timbul.

\section{Hasil dan Pembahasan}

Melansir dari Catatan Rapat Badan Legislasi Pengambilan Keputusan Atas Penyusunan Rancangan Undang-Undang Tentang Haluan Ideologi Pancasila tanggal 22 April 2020, RUU HIP adalah RUU yang diusulkan oleh DPR RI dan disebut telah ditetapkan dalam Prolegnas RUU Prioritas Tahun 2020. Berdasarkan catatan rapat tersebut, dikatakan bahwa saat ini belum ada undang-undang sebagai sebagai landasan hukum yang mengatur mengenai Haluan Ideologi Pancasila untuk menjadi pedoman bagi kehidupan berbangsa dan bernegara sehingga diperlukan Undang-undang tentang Haluan Ideologi Pancasila. ${ }^{8}$ Permasalahan timbul dan menjadi polemik berawal dari tidak dicantumkannya TAP MPRS Nomor 25/MPRS/1966 Tahun 1966 tentang Pembubaran Partai Komunis Indonesia, Pernyataan Sebagai Organisasi Terlarang Diseluruh Wilayah Negara Republik Indonesia Dan Larangan Setiap Kegiatan Untuk Menyebarkan Atau Mengembangkan Faham Atau Ajaran Komunis /Marxisme Leninisme. Hal tersebut dianggap sebagai bentuk pengabaian terhadap sejarah yang terjadi di Negara Indonesia terhadap hal yang dilakukan oleh Partai Komunis Indonesia di masa lalu.

Selain hal itu, memeras Pancasila menjadi Trisila lalu menjadi Ekasila dianggap merupakan upaya untuk mengesampingkan

\footnotetext{
7 ) Soerjono Soekanto, Metode Penelitian Hukum, (Jakarta: Universitas Indonesia Press, 1986), hal 8.

${ }^{8}$ Nur Rohmi Aida. “Apa Itu RUU HIP yang Dipersoalkan NU dan Muhammadiyah?”. https://www.kompas.com/tren/read/2020/06/17/0625597 65/apa-itu-ruu-hip-yang-dipersoalkan-nu-danmuhammadiyah?page $=$ all. 23 Juni 2020
} 
makna dari Pancasila dan dianggap ingin menghilangkan Sila Pertama Pancasila yaitu Ketuhanan Yang Maha Esa yang telah termaktub dalam Pasal 29 ayat (1) UUD Tahun 1945. Disadur dari draf RUU HIP, konsep Trisila dan Ekasila tertuang di dalam Pasal 7. Pasal tersebut memuat tiga ayat yang isinya sebagai berikut:

1. Ciri pokok Pancasila adalah keadilan dan kesejahteraan sosial dengan semangat kekeluargaan yang merupakan perpaduan prinsip ketuhanan, kemanusiaan, kesatuan, kerakyatan/demokrasi politik dan ekonomi dalam satu kesatuan.

2. Ciri pokok Pancasila berupa trisila, yaitu sosio-nasionalisme, sosio-demokrasi, serta ketuhanan yang berkebudayaan.

3. Trisila sebagaimana dimaksud pada ayat (2) terkristalisasi dalam ekasila, yaitu gotong royong.

Dengan demikian hal ini adalah bentuk pengingkaran terhadap keberadaan Pembukaan dan Batang Tubuh UUD 1945 sebagai Dasar Negara, sehingga hal ini dianggap sebagai pembubaran NKRI yang berdasarkan pada 5 Sila tersebut.

Berdasarkan teori Gustav Radburch, hukum harus mengandung tiga nilai identitas yaitu: ${ }^{9)}$

1. Asas keadilan hukum (gerectigheit) yang meninjau dari sudut filosofis;

2. Asas kemanfaatan hukum (zwechmatigheid) atau doelmatigheid atau utility yang meninjau dari sudut sosiologis;

3. Asas kepastian hukum (rechtmatigheid) yang meninjau dari sudut yuridis.

Radburch yang tesisnya sudah diterima luas oleh komunitas ilmu hukum, mengatakan, bahwa citra hukum tersebut ditopang oleh kehadiran tiga nilai dasar (grundwerten), yaitu keadilan (gerectigheit), kemanfaataan (zwek-

9 ) Hardi Munte, "Model Penyelesaian Sengketa Administrasi Pilkada", (Jakarta: Penerbit Puspantara, 2017), hlm. 27. maerten), dan kepastian hukum (rechtssichterkeit). Ketiga nilai dasar itu tidak selalu berada dalam hubungan yang harmonis satu sama lain, melainkan berhadapan dan bertentangan satu sama lain.

Keadilan bisa bertabrakan dengan kemanfaatan dan kepastian hukum. Tuntutan kemanfaatan bisa juga bertabrakan dengan keadilan dan kepastian hukum dan seterusnya. Kepastian hukum atau rechtssicherkeit, security, rechtzekerheit adalah sesuatu yang baru, yaitu sejak hukum ditulis, dipositifkan, dan menjadi publik. Pada mulanya ajaran dari Gustav Radburch dirasakan jauh lebih maju dan arif ketimbang "ajaran ekstrem" yaitu ajaran etis, utilistis, dan dogmatic legalistik, namun lama-kelamaan karena semakin kompleknya kehidupan manusia di era modern ini, maka pilihan prioritas yang sudah dibakukan, terkadang memunculkan pertentangan antara kebutuhan hukum dan kasus-kasus tertentu.

Adakalanya dalam suatu kasus keadilan yang lebih tepat diprioritaskan ketimbang kemanfaatan dan kepastian hukum, tetapi dalam kasus lain justru terasa lebih tepat jika kemanfaatan lebih diprioritaskan ketimbang keadilan dan kepastian hukum; dan mungkin lagi dalam kasus lainnya justru kepastian hukum yang lebih tepat diprioritaskan ketimbang keadilan dan kemanfaatan. Konsep termutakhir ini yang oleh dunia praktik hukum yang dianggap paling relevan untuk menjawab masalah-masalah hukum dewasa ini. Jadi dalam hal ini segi efektifitas dan efisiensi "doelmatigheid" merupakan hal-hal yang sangat diperhatikan dalam hukum tata usaha negara maupun hukum administrasi negara. Idealnya kepastian hukum (rechtssicherheit), kemanfaatan (zweckmassigheit), dan keadilan (gerechtigheit) sebisa mungkin ada dalam putusan secara proposional, tapi di dalam prakteknya jarang terdapat putusan yang mengandung tiga unsur itu secara proposional. ${ }^{10)}$

${ }^{10)}$ Ibid., hal.29. 
Berdasarkan hal itu, maka bisa dikatakan Rancangan Undang-Undang Haluan Ideologi Pancasila tidak memiliki kepastian dan kemanfaatan hukum karena Rancangan UndangUndang tersebut tidak sesuai dengan Pancasila yang menjadi sumber dari segala sumber hukum yang ada di Indonesia, dan Rancangan Undang-Undang tersebut tidak memiliki kemanfaatan karena menimbulkan kegaduhan bagi masyarakat.

Indonesia sebagai negara hukum berdasarkan pendapat Notohamidjojo menggunakan rechtstaat dalam pengertian negara hukum, demikian pula halnya Muhammad Yamin yang menggunakan rechtstaat, government of law dalam pengertian negara hukum, di samping menggunakan istilah rechtstaat, ada juga yang menggunakan istilah the rule of law. ${ }^{11)}$ Albet Van Dicey mengemukakan bahwa ada tiga unsur utama negara hukum, yaitu:

1. Supermasi hukum (Supermacy of law), artinya bahwa yang mempunyai kekuasaan yang tertinggi di dalam negara adalah hukum (kedaulatan hukum), tidak ada peradilan administrasi (tidak adanya pemisahan peradilan bagi pejabat dan publik);

2. Persamaan kedudukan dalam hukum bagi setiap orang (Equality before the law).

3. Konstitusi tidak merupakan sumber dari hak-hak asasi manusia dan jika hak-hak asasi manusia itu diletakkan dalam konstitusi, konstitusi harus melindunginya.

Munculnya pemikiran tentang Negara hukum sebenarnya dimulai sejak abad XIX sampai dengan abad XX. Arti negara hokum itu sendiri pada hakikatnya berakar dari konsep teori kedaulatan hukum yang pada prinsipnya menyatakan bahwa kekuasaan tertinggi di dalam suatu negara adalah hukum. Oleh sebab itu, seluruh perlengkapan negara harus tunduk

11) Iriyanto A.Baso Ence, Negara Hukum dan Hak Uji Konstitusionalitas Mahkamah Konstitusi, (PT Alumni, Bandung:2008), hal.13. dan patuh serta menjunjung tinggi hokum tanpa kecuali. Krabe mengemukakan :

"Negara sebagai pencipta dan penegak hukum di dalam segala kegiatannya harus tunduk pada hukum yang berlaku. Dalam arti ini hukum membawahkan negara. Berdasarkan pengertian hukum itu bersumber dari kesadaran hukum rakyat, maka hukum mempunyai wibawa yang tidak berkaitan dengan seseorang (impersonal)".

Berdasarkan konsep teori inilah berkembang konsep negara hukum yang menghendaki adanya unsur-unsur tertentu dalam penyelenggaraan sistem ketatanegaraan yaitu: ${ }^{12)}$

1. Jaminan Hak Asasi Manusia (warganegara)

Unsur ini ditempatkan pertama kali karena sejatinya negara itu terbentuk karena adanya kontak sosial. Dari kontak social inilah individu-individu dalam ikatan kehidupan bersama dalam Negara menyerahkan hak-hak politik dan sosialnya kepada komunitas negara, maka negara harus memberikan jaminan kepada hak-hak yang melekat di dalam individu- individu maupun di dalam ikatan kehidupan kemasyarakatan. Hal ini bisa terjadi, karena di dalam kontrak sosial tersebut kedudukan antara negara sebagai suatu ikatan organisasi di satu pihak dengan warga Negara secara keseluruhan di pihak lain adalah sejajar. Masing-masing mempunyai hak dan kewajiban yang sama, oleh sebab itulah diantara keduanya harus saling memberikan perlindungan, dan karenan negara adalah organisasi kekuasaan dimana sifat kodrati kekuasaan itu cenderung disalahgunakan maka kewajiban untuk melindungi hak-hak asasi warga Negara menjadi mutlak dan diletakkan dalam

12 ) B.Hestu Cipto Handoyo, Hukum Tata Negara Indonesia, (Universitas Atma Jaya Yogyakarta, Yogyakarta:2009), hal.17. 
tanggung jawab maupun tugas dari negara.

2. Pemisahan atau Pembagian kekuasaan Untuk memberikan jaminan terhadap perlindungan hak-hak asasi manusia, maka kekuasaan di dalam negara harus dipisahpisah dan dilaksanakan oleh beberapa organ negara. Sejarah peradaban manusia membuktikan bahwa ketika kekuasaan itu dilaksanakan secara absolut oleh satu tangan dan dilaksanakan secara otoriter karena tidak dilandasi aturan main, maka terjadilah penindasan terhadap harkat dan martabat kemanusiaan, oleh sebab itulah antara kekuasaan menjalankan pemerintahan (eksekutif), kekuasaan membentuk perundang-undangan (legislatif), dan kekuasaan melaksanakan peradilan (yudikatif) harus dipisahkan. Implementasi dari prinsip pemisahan kekuasaan ini dapat beraneka ragam. Ada yang kelembagaan sedangkan mengenai fungsi dan tugasnya masih bisa saling berhubungan. Ada juga yang berdimensi pemisahan secara tegas baik secara kelembagaan maupun fungsi dari masing-masing pemegang kekuasaan tersebut. Terlepas dari implementasi tersebut, pada hakikatnya unsur adanya pemisahan atau pembagian kekuasaan yang ada di dalam organisasi kekuasaan yang disebut negara tetap bertujuan agar kekuasaankekuasaan itu tidak disalahgunakan yang pada akhirnya justru menindas harkat dan martabat kemanusiaan dari warga negara.

\section{Asas Legalitas Pemerintahan}

Maksud dari asas ini adalah pemerintah dalam melaksanakan tugas dan tanggungjawabnya harus berdasarkan pada hukum atau peraturan perundang-undangan yang berlaku. Hukum harus menjadi landasan bagi negara dalam menjalankan pemerintahan.
4. Prinsip Peradilan yang bebas dan tidak memihak

Prinsip seperti ini bagi negara hokum sangatlah penting. Supermasi hukum yang diletakan dalam kehidupan ketatanegaraan harus benar-benar terjamin pelaksanaannya. Peradilan yang bebas dan tidak memihak tidak semata-mata diletakkan dalam konteks kebebasan lembaga peradilan, yakni melalui prinsip independensi hakim, melainkan harus diletakkan dalam konteks proses peradilan dalam rangka penegakan hukum (law enforcement), dengan demikian dalam mekanisme proses peradilan yang harus bebas dan tidak memihak menyangkut organ-organ penegak hukum, seperti hakim, jaksa, Kepolisian, maupun para pengacara.

Unsur-unsur yang terdapat di dalam konsep negara hukum yang demikian ini, menjadikan negara berperan sebagai pencipta hukum sekaligus penegak hukum dalam rangka menjaga keamanan dan ketertiban hidup bersama dalam ikatan organisasi kekuasaan yang disebut negara. Kendati negara adalah pencipta hukum namun negara harus tetap tunduk pada hukum ciptaannya. Argumentasi inilah yang mengakibatkan negara hanya berfungsi layaknya penjaga malam. Artinya negara berfungsi menciptakan hukum, dan melalui hokum ciptaannya itulah diharapkan dapat tercipta keamanan dan ketertiban di dalam negara. Negara hanya dikonstruksikan sebagai alat untuk menjunjung tinggi keamanan dan ketertiban hidup bersama. Konsepsi seperti ini kemudian lazim disebut Negara Hukum Formal. $^{13)}$

Seturut dengan perkembangan pemikiran mengenai negara dan hukum, unsur-unsur yang terdapat di dalam konsep negara hukum formal tersebut di atas juga mengalami perkembangan. Pendek kata, dalam perkembangan pemikiran negara dan hukum, tugas dan fungsi

${ }^{13)}$ Ibid., hal.19. 
negara tidak hanya terbatas pada konstruksi tugas dan fungsi ketiga kekuasaan yang ada (legislatif, eksekutif, dan yudikatif) serta menjaga keamanan dan ketertiban. Hal ini mengingat semakin beragamnya kehidupan masyarakat (warga negara) dengan berbagai macam dimensi yang ada di dalamnya. Pola-pola kehidupan dan kegiatan dari warga negara makin lama sukar untuk dipisahkan dengan pola dan kegiatan yang dilakukan oleh negara (pemerintah). Dalam lingkungan warga negara muncul organisasi-organisasi yang manifestasinya juga mengarah kepada kekuasaan, seperti partai politik, golongan fungsional, dan lain sebagainya. Negara tidak hanya sebatas sebagai pencipta hukum untuk menjaga keamanan dan ketertiban, melainkan sudah mulai ikut terlibat dalam meningkatkan kesejahteraan umum dari warga negaranya. Berdasarkan pola pergeseran fungsi dan tugas negara inilah, maka paham negara formil juga mengalami perubahan.

Unsur-unsur negara hukum formil yang dulunya begitu kuat untuk dipertahankan (negara sebagai penjaga malam) mulai mengalami pergeseran dan ditambah, yaitu kewajiban bagi negara untuk ikut terlibat dalam membantu meningkatkan kesejahteraan umum warga negara, dari sinilah konsepsi negara hokum formil berikut unsur-unsur yang terkandung di dalamnya mulai berganti dengan konsep negara hukum modern atau negara kesejahteraan (welfare state) yang lazim juga disebut sebagai negara hukum materiil. Dalam negara hokum materiil, fungsi negara di samping mempertahankan dan melaksanakan hukum semaksimal mungkin, juga dituntut untuk mampu meningkatkan kesejahteraan hidup warga negaranya argumentasi yang demikian ini menjadikan negara tidak hanya bertindak laksana penjaga malam, melainkan yang terpenting dan utama adalah bertindak sebagai pelayan masyarakat (public services), dalam rangka meningkatkan kesejahteraan umum warga negaranya.

Tugas dan fungsi negara dalam konsep negara hukum materiil menjadi sedemikian luas sampai menjangkau kehidupan masyarakat di bidang sosial budaya, ekonomi, politik, agama, teknologi, pertahanan keamanan, bahkan kalau perlu sampai masuk kehidupan privat warga negara (misalnya mengatur mengenai perkawinan, agama, dan sebagainya). Dengan demikian unsur terpenting dari negara hokum materiil (welfare state) adalah $:^{14)}$

1. Jaminan terhadap hak-hak asasi manusia;

2. Pemisahan/pembagian kekuasaan;

3. Legalitas Pemerintahan

4. Peradilan Administrasi yang bebas dan tidak memihak; dan

5. Terwujudnya kesejahteraan umum warga negara .

Lain halnya dengan Stahl, menurut Stahl unsur-unsur negara hukum (rechtstaat) adalah : ${ }^{15)}$

1. Perlindungan hak-hak asasi manusia;

2. Pemisahan atau pembagian kekuasaan untuk menjamin hak-hak itu;

3. Pemerintahan berdasarkan Peraturan Perundang-undangan ;

4. Peradilan administrasi dalam perselisihan.

Negara dalam konsep negara hukum selanjutnya harus menjamin tertib hukum (rechtstorde), menjamin tegaknya hukum dan menjamin tercapainya tujuan hukum, yaitu keadilan, kepastian hukum dan kemanfaatan hukum, A. Hamid S., Attamimi memberi pengertian tertib hukum sebagai suatu kesatuan hukum objektif yang keluar tidak bergantung kepada hukum yang lain, dan ke dalam menentukan semua pembentukan hukum dalam suatu kesatuan tertib hukum tersebut. Rumusan ini sangat penting dalam menentukan ada atau tidaknya kesatuan yuridis dalam suatu tertib hukum. J.H.A Logemann mengatakan bahwa sama seperti tertib masyarakat, yang merupakan suatu keseluruhan yang saling berkaitan, juga hukum positif, yang ditemukan dengan

\footnotetext{
14) Ibid., hal.21.

15) Ridwan HR, Hukum Asministrasi Negara, (Jakarta: PT RajaGrafindo Persada, 2006), hlm.3.
} 
mengabstraksikan dari suatu keseluruhan, suatu ketalian norma-norma, ialah suatu tertib hukum, dengan demikian dalam hukum positif tidak terdapat norma-norma yang saling bertentangan. Berdasarkan uraian di atas dapat disimpulkan bahwa tata tertib hukum tercipta bahwa. ${ }^{16)}$

a. Suatu produk peraturan perundangundangan tidak saling bertentangan, baik secara vertikal maupun secara horizontal.

b. Perilaku anggota masyarakat sesuai dengan aturan hukum yang berlaku.

Konsep hukum lain dari negara berdasarkan atas hukum adalah adanya jaminan penegakan hukum dan tercapainya tujuan hukum, dalam penegakan hukum terdapat tiga unsur yang selalu harus mendapat perhatian yaitu keadilan, kemanfaatan atau hasil guna dan kepastian hukum. ${ }^{17)}$

Oleh karena itu, sudah seharusnya Rancangan Undang-Undang tentang Haluan Ideologi Pancasila tidak dilanjutkan karena Indonesia sebagai negara hukum, dimana Ideologi Pancasila sebagai jalan hidup negara, sudah seharusnya dipertahankan, bukan dirubah atau dihilangkan beberapa sila di dalam Pancasila.

\section{Simpulan}

Berdasarkan pemaparan yang sudah disampaikan, simpulan mengenai Analisis Yuridis Tentang Rancangan Undang-Undang Haluan Ideologi Pancasila yaitu :

1. Berdasarkan tidak dicantumkannya TAP MPRS No. XXV/MPRS/1966 Tahun 1966 tentang Pembubaran Partai Komunis Indonesia dan Larangan Setiap kegiatan Untuk Menyebarkan Atau Mengembangkan Faham atau Ajaran Komunisme/ Marxisme - Leninisme, menjadi latar belakang yang cukup kuat untuk menolak RUU HIP karena bangsa Indonesia tidak

\footnotetext{
16) Ibid., hal.19.

${ }^{17)}$ Loc.cit.
}

bisa melupakan tragedi berdarah Gerakan 30 September PKI dan peristiwa-peristiwa berdarah sebelumnya yang melatarbelakangi diterbitkannya Ketetapan MPRS tersebut. Larangan menyebarkan atau mengembangkan ajaran Komunisme/ Marxisme - Leninisme tersebut oleh Undang-Undang No. 27 Tahun 1999 Tentang Perubahan Kitab Undang-Undang Hukum Pidana Yang Berkaitan Dengan Kejahatan Terhadap Keamanan Negara, diancam dengan pidana penjara paling lama 12 (dua belas) tahun.

2. Konsep Rancangan Undang-Undang Haluan Ideologi Pancasila yang memuat pokok-pokok pikiran dan keyakinan yang menjadi ruh dari RUU tersebut. Pancasila bisa diperas menjadi trisila (sosio-nasionalisme, sosio-demokrasi, dan ketuhanan yang berkebudayaan) dan diperas lagi menjadi ekasila (gotong- royong). Pemahaman seperti itu merupakan penyelewengan terhadap Pancasila, dan karenanya harus ditolak. Apa yang dinyatakan dalam RUU HIP tersebut bukan gagasan baru. Hal itu merupakan gagasan lama yang sejarah telah membuktikan kegagalannya. Gagasan itu akan mengingatkan bangsa Indonesia pada doktrin Nasakom (Nasionalisme, Agama, dan Komunisme), PKI (Partai Komunis Indonesia) dan peristiwa G 30S PKI.

Pancasila dalam kehidupan berbangsa dan bernegara merupakan norma paling tinggi dan dasar falsafah negara. Sehingga perumusan Pancasila pada tingkat norma Undang-Undang menurunkan nilai Pancasila sebagai dasar falsafah bangsa dan merendahkan posisi Pancasila. Oleh karena itu, sebaiknya kepada para Fraksi-Fraksi di DPR RI tidak melanjutkan Rancangan Undang-Undang Haluan Ideologi Pancasila karena akan merubah tatanan kehidupan berbangsa dan bernegara masyarakat Indonesia. 


\section{DAFTAR PUSTAKA}

\section{Buku}

Asshiddiqie, Jimly dan Ali Safa'at, 2012, Teori Hans Kelsen Tentang Hukum, Konstitusi Press, Jakarta

Basah, Sjahran, 1985, Eksistensi dan tolak ukur badan peradilan administrasi negara di Indonesia, Cet ke 3, Alumni, Bandung

Ence, Iriyanto A. Baso, 2008, Negara Hukum dan Hak Uji Konstitusionalitas Mahkamah Konstitusi, PT. Alumni, Bandung

Made, I Pasek Diantha, 2016, Metodologi Penelitian Hukum Normatif, PT Kharisma Putra Utama, Jakarta

Munte, Hardi, 2017, "Model Penyelesaian Sengketa Administrasi Pilkada", Puspantara, Jakarta

Notonogoro, 1983, Pancasila dasar falsafah negara, kumpulan tiga uraian pokokpokok persoalan tentang Pancasila. Cetakan kelima, Bina Aksara, Jakarta

Soerjono Soekanto, 1986, Metode Penelitian Hukum, Universitas Indonesia Press, Jakarta
Soekanto, Soerjono dan Sri Mamudji, 2004, Penelitian Hukum Normatif, PT. Raja Grafindo Persada, Jakarta

\section{Internet}

Nur Rohmi Aida. “Apa Itu RUU HIP yang Dipersoalkan NU dan Muhammadiyah?". https://www.kompas.com/tren/read/20 20/06/17/062559765/apa-itu-ruu-hipyang-dipersoalkan-nu-danmuhammadiyah?page=all. 23 Juni 2020 